\title{
Serological Status of Newcastle Disease Virus in Live Broiler Birds of Mansehra Khyberpakhtunkhwa Pakistan
}

\author{
Sadaqat Khurshid* and Ihsan ur Rahman \\ Department of Microbiology Hazara University Mansehra kpk, Pakistan
}

Submission: August 21, 2018; Published: September 20, 2018

*Corresponding author: Sadaqat Khurshid, Department of Microbiology Hazara University Mansehra kpk Pakistan, Email: ihsan.hu20@gmail.com

Abstract

This study was conducted to recognize the serological status of Newcastle disease virus in live broiler poultry grown local area of district mansehra. A total of 248 samples from different age groups ( $0-3,3-5,5-7$ week) of vaccinated $(n=144)$ and non-vaccinated ( $n=104)$ broiler poultry population were collected from different areas of District Mansehra. Haemagglutination Inhibition (HI) test 16 samples were sero-negative in non-vaccinated flock and remaining samples were sero-positive. From vaccinated samples, only three samples were detected sero-negative and all remaining 141 samples were sero-positive. Percentage sero-prevalence of NDV in non-vaccinated broiler poultry flock of district Mansehra was found to be $84 \%$, whereas percentage sero-postive in vaccinated flock were $97 \%$. Such a high prevalence of NDV infection in non-vaccinated broiler poultry flocks is a future risk for the outbreak of disease in the broiler and all other bird species including breeders. The level of protection of the vaccinated birds was found unsatisfactory which indicate that present strategies were not fully effective in case of this infection.

Keywords: Newcastle Disease virus; Serum Antibodies; Haemagglutination; Haemagglutination Inhibition

Abbreviations: HI: Haemagglutination Inhibition; ND: Newcastle Disease; IBD: Infectious Bursal Disease; IB: Infectious Bronchitis; EDS: Egg Drop Syndrome; HPS: Hydropericardium Syndrome; AI: Avian Influenza

\section{Introduction}

In developing country Poultry is a big source to get poultry production. In Pakistan the poultry investment is about 1 billion US dollar in poultry sector. The animal protein and the eggs availability is directly proportional to the broiler meat availability. Which is increasingly by $4 \%$ annually. the family in urban areas suffer more from the poultry production activities in same or different ways than the family of rural areas [1]. The major thing which is involved in spreading of such kind problem is infectious disease this infectious disease is due to disseminated agent in poultry production sector. There are different agents in country that cause disease in poultry and their products diseases are Newcastle disease (ND). infectious bursal disease (IBD), Infectious Bronchitis (IB) and Egg Drop Syndrome, (EDS). Hydropericardium syndrome (HPS), and Avian Influenza virus (AI), these diseases may cause economical loss of poultry and their product by causing mortality, reduce the production of egg, hatchability. stress, morbidity across the world including Pakistan [2] NDV are considered to be the rich source of causing mortality in chicken [3] and many other species like wild birds and domesticated found to be susceptible to NDV [4-6]. The dessimination of NDV is nearly normal through new birds, selling or giving away sick and carrier birds [7]) regarding to this situation This study was designed to evaluate the prevalence of Newcastle disease virus antibodies in different age group of vaccinated and non-vaccinated chicken from different forms of district Abbottabad.

\section{Materials and Methods}

\section{Collection of samples}

The current research work was conducted in virology laboratory at Veterinary Research and Disease Investigation Centre (VR\&DIC), Mandian, Abbottabad, Pakistan, study duration was February to August 2017. Total 248 blood sample were collected from different forms of district mansehra.

For the collection of serum from broilers poultry blood, samples were incubated for one hour in incubator at $37{ }^{\circ} \mathrm{C}$ to warm the samples for easy collection of serum. After incubation, the samples were centrifuged at $3000 \mathrm{rpm}$ for 10 minutes. The serum was collected in the Eppendorf tubes from centrifuged samples, labelled and stored at $-20{ }^{\circ} \mathrm{C}$ for further use For Haemagglutination Inhibition (HI) Test.

\section{Haemagglutination inhibition test}

The sample were tested to find whether the test is positive or negative against NDV By HI test [8]. A prepared antigen was used in $\mathrm{HI}$ for NDV,5 ml blood was collected from every chicken 
in a disposable syringe aseptically and added $1 \mathrm{ml}$ anticoagulant i.e., sodium citrate (4\%solution) to blood. after this for 15 minutes the blood was centrifuged at rate of $1500 \mathrm{rpm}$ then the buffy coat and plasma was removed from samples. Now it was washed with PBS thrice time in HI test only $1 \%$ RBC'S suspension in phosphate buffer saline was used. this test was performed according to the Allan and Gough [8]. Guidline.in shortly up to 10 th well 2 fold serial dilution were made then four HA unit of NDV added to 11th well and stored for 25-30 minutes at $25-30{ }^{\circ} \mathrm{C}$. In each well there was only $1 \%$ of chicken RBC'S suspension added the positive samples was observed as a central button shaped settling of red blood cell and the HI end point was considered at maximum dilution of each samples. the hemagglutination inhibition titer was found reciprocal of serum dilution.

\section{Results}

\section{Distribution of birds on basis of their age and vaccine}

History: Total 248 blood samples were collected after visiting the 30 commercial broiler farms. Samples were collected on the basis of vaccinated and not vaccinated farms as the farmers reported. For Newcastle disease virus antibodies titration, 144 blood samples were collected from 17 vaccinated forms of birds, whereas 104 blood samples were collected from 13 non-vaccinated farms of birds. Serum were separated from blood samples and store at -20 0C. For detection of antibodies in blood sera, HI test was performed in V-bottom micro titter plates. The present study, the chickens were divided into three different age groups as shown in Table $1 \& 2$ Haemagglutination pattern of serially diluted NDV for determination of HA titter.

Table 1: Number of vaccinated and non-vaccinated birds on basis of different age group.

\begin{tabular}{|c|c|c|}
\hline Age of Birds & Vaccinated birds' Samples & Non-Vaccinated birds Samples \\
\hline $1-3$ week & 32 & 24 \\
\hline $3-5$ week & 56 & 40 \\
\hline $5-7$ week & 56 & 40 \\
\hline Total & 144 & 104 \\
\hline
\end{tabular}

Table 2: Serially diluted NDV for determination of HA titter.

\begin{tabular}{|c|c|c|c|c|c|c|c|c|c|c|c|c|}
\hline Well & $\mathbf{1}$ & $\mathbf{2}$ & $\mathbf{3}$ & $\mathbf{4}$ & $\mathbf{5}$ & $\mathbf{6}$ & $\mathbf{7}$ & $\mathbf{8}$ & $\mathbf{9}$ & $\mathbf{1 0}$ & $\mathbf{1 1}$ & $\mathbf{1 2}$ \\
\hline Dilution & 10 -Jan & 20 -Jan & Jan-40 & Jan-80 & Jan- 60 & $1 / 320$ & $1 / 640$ & $1 / 1280$ & Jan- 60 & Jan- 20 & $1 / 10240$ & Control \\
\hline
\end{tabular}

Agglutination appears as a mat of RBC that covering the bottom of the well. Hemagglutination occurred up to well 8 in vaccinated birds whereas from 9 to 11 well showed no agglutination. In non-vaccinated birds aggulutination occurred up to well 6, whereas from well 7-11 showed no agglutination. Well 12 was left as a control.

\section{Percentage of sero prevalence of NDV in different age}

\section{Groups by Using Hi Test}

1-3-week age group: Three poultry farms with birds of age ranging from 0-3 week were visited and 24 samples were collected. These birds were non-vaccinated. Among all 24 samples, 18 were seropositive (75\%) while 6 were sero-negative

Table 3: Serological status of non-vaccinated broilers poultry birds samples showing positive and negative results to NDV using HI test.

\begin{tabular}{|c|c|c|c|c|c|c|}
\hline Age of birds & $\begin{array}{c}\text { Broilers birds' } \\
\text { samples }\end{array}$ & $\begin{array}{l}\text { Antibodies } \\
\text { against NDV }\end{array}$ & $\begin{array}{l}\text { +ive samples for } \\
\text { NDV antibodies }\end{array}$ & $\begin{array}{l}\text {-ive samples for } \\
\text { NDV antibodies }\end{array}$ & $\begin{array}{c}\% \text { of }+ \text { ive } \\
\text { samples for NDV } \\
\text { antibodies }\end{array}$ & $\begin{array}{c}\% \text { of -ive } \\
\text { samples for NDV } \\
\text { antibodies }\end{array}$ \\
\hline 1-3 week & 24 & + & 18 & 6 & 75 & 25 \\
\hline 3-5 week & 40 & + & 33 & 7 & 82 & 18 \\
\hline 5-7 week & 40 & + & 37 & 3 & 92.5 & 7.95 \\
\hline Total & 104 & + & 88 & 16 & 84 & 16 \\
\hline
\end{tabular}




\section{Advances in Biotechnology \& Microbiology}

Table 4: Serological status of vaccinated broilers birds' samples showing positive and negative results to NDV using HI test.

\begin{tabular}{|c|c|c|c|c|c|c|}
\hline Age of birds & $\begin{array}{c}\text { Broilers birds' } \\
\text { samples }\end{array}$ & $\begin{array}{c}\text { Antibodies } \\
\text { against NDV }\end{array}$ & $\begin{array}{c}\text { +ive samples for } \\
\text { NDV antibodies }\end{array}$ & $\begin{array}{c}\text {-ive samples for } \\
\text { NDV antibodies }\end{array}$ & $\begin{array}{c}\text { \% of +ive samples for } \\
\text { NDV antibodies }\end{array}$ & $\begin{array}{c}\text { \% of -ive samples } \\
\text { for NDV antibodies }\end{array}$ \\
\hline 1-3 week & 32 & + & 29 & 3 & 90.62 & 9.38 \\
\hline 3-5 week & 56 & + & 56 & None & 100 & None \\
\hline 5-7 week & 56 & + & 56 & None & 100 & None \\
\hline Total & 144 & + & 141 & 3 & 97 & 3 \\
\hline
\end{tabular}

5-7-week age group: 40 samples from non-vaccinated birds with age range between 5-7 week were collected from 4 forms and tested for sero-prevalence. Only 3 samples (7.95\%) were detected sero-negative out of 40 birds' samples and remaining all samples were sero-positive for NDV with percentage $92.5 \%$ as shown in Table 3.

Similarly, 56 samples were collected from vaccinated chicken by visiting 7 farms. All of these samples were sero-positive (100\% sero-prevalence) as shown in Table 4 . The antibodies titrations of positive samples are recorded in Table $4 \& 5$. The antibodies highest titration was $10 \log 2$, while $2 \log 2$ were the lowest titrations. Those Samples having antibodies titration

$2 \log 2$ or below $2 \log 2$ were recorded as negative because they produce no antibody against the virus. Samples were considered positive for NDV antibodies that had NDV antibody titer 3log2 and above $3 \log 2$.

In non-vaccinated flock, out of the 104-serum tested, 16 (15.38\%) birds were negative for NDV antibody, because they had the antibody titer below the minimum protective titer of $3 \log 2$ (i.e 4 birds had NDV antibody titer of $2 \log 1$ and 2 chickens had NDV antibody titer of 2log2). The remaining chickens were positive for NDV antibody having NDV antibody titer $3 \log 2$ and above $3 \log 2$ (Table 5).

Table 5: Haemagglutination inhibition titers of different age group of not vaccinated broiler poultry against Newcastle disease virus.

\begin{tabular}{|c|c|c|c|c|c|c|c|c|c|c|c|}
\hline & & \multicolumn{10}{|c|}{ Antibody titers by using $\mathrm{HI}$ test } \\
\hline $\begin{array}{c}\text { Age } \\
\text { (weeks) }\end{array}$ & No. Of Samples & $\log _{2}$ & $2 \log _{2}$ & $3 \log _{2}$ & $4 \log _{2}$ & $5 \log _{2}$ & $6 \log _{2}$ & $7 \log _{2}$ & $8 \log _{2}$ & $9 \log _{2}$ & $10 \log _{2}$ \\
\hline $0-3$ & 24 & 4 & 2 & 5 & 4 & 6 & 3 & & & & \\
\hline 5-Mar & 40 & 1 & 6 & 6 & 7 & 8 & 5 & 1 & 3 & 2 & \\
\hline 7-May & 40 & & 3 & 4 & 3 & 7 & 5 & 4 & 4 & 6 & 4 \\
\hline
\end{tabular}

In vaccinated flock, 144 serum samples were tested out of which 141 (97\%) birds were seropositive for NDV antibodies. Results in Table 6 indicate that a higher percentage of the chickens (54\%) had protective NDV antibodies between $6 \log 2$

Table 6: Haemagglutination inhibition titers of different age group of vaccinated broiler poultry against Newcastle disease virus.

\begin{tabular}{|c|c|c|c|c|c|c|c|c|c|c|c|}
\hline \multicolumn{12}{|c|}{ Antibody titers by using $\mathrm{HI}$ test } \\
\hline Age (weeks) & No. Of Samples & $\log _{2}$ & $2 \log _{2}$ & $3 \log _{2}$ & $4 \log _{2}$ & $5 \log _{2}$ & $6 \log _{2}$ & $7 \log _{2}$ & $8 \log _{2}$ & $9 \log _{2}$ & $10 \log _{2}$ \\
\hline $0-3$ & 32 & 1 & 2 & 5 & 9 & 6 & 5 & 4 & & & \\
\hline 5-Mar & 56 & & & 7 & 6 & 4 & 5 & 9 & 13 & 5 & 7 \\
\hline 7-May & 56 & & & 1 & 4 & 5 & 3 & 14 & 16 & 6 & 8 \\
\hline
\end{tabular}

\section{Discussion}

From many countries, Newcastle disease virus has been reported including Pakistan where it causes a huge loss of poultry industry. The mortality rate of birds is very high due to NDV infection. It causes a deadly disease in chickens, turkeys and many other birds. The serological tests are very appropriate for surveillance and early detection of NDV infection. In this respect, four major tests are used, that is ELISA, HI, agar gel immune diffusion and PCR. For early detection of infection in diagnostic laboratory $\mathrm{HI}$ test is most suitable. Hence, in the current study, Haemagglutination inhibition was used to find the serological status finding of NDV. Blood samples were collected from 30 broiler farms of District Mansehra between February, to August 2017. A total 248 samples, on the basis of birds age group and vaccination related with Newcastle disease, were collected. and $8 \log 2$. The result of HI test show that antibody titers in nonvaccinated birds flocks was significantly lower than vaccinated flocks.

The antibody titrations of these samples were detected in laboratory. In non-vaccinated flocks, about $84 \%$ samples found positive for antibody against NDV. It means that the broilers birds were naturally exposed to NDV, while in vaccinated flocks, 97\% samples were sero-positive. During the study, it was observed that in non-vaccinated birds, relatively high level of antibodies are present which indicate NDV infections have high prevalence in broiler chickens. The detectable level of antibodies against NDV shows that birds are naturally exposed to virus. In vaccinated flocks of Pakistan, a number of outbreaks of NDV have been reported [9]. Many field studies in past indicated that outbreaks in vaccinated birds occur due to new viral strains introduction, against which chicken have no or low immunity, thus results in vaccine failure. This also occurs due to improper vaccination practices [10]. 
The antibody titter that recorded against NDV ranged between from $2 \log 2-10 \log 2$. Antibody titre below $2 \log 2$ was considered negative and antibody titter that was $\geq 3 \log 2$ was considered positive. Infection occurs in different stages of life so variation showed by antibody titration. For detection of NDV serology in birds, Rezaeinazadeh, et al. [11] conducted a survey in Fars Province by using serological tests. He concluded that $61.9 \%$ bird were sero-positive. Hadipur [12], conducted a study in which $37.56 \%$ chicken were detected sero- positive. In another survey on broiler birds in Iraq, show that $34.4 \%$ samples were seropositive by HI test for NDV [13]. In another report from Bangladesh, total 78.04\% broiler birds were seropositive for NDV antibodies.

The 30-45 days of broilers birds are most often infected with NDV. The highest antibody titter $7 \log 2$ to $8 \log 2$ is considered protected against NDV. The present study show that $54 \%$ vaccinated chickens of age 5-7 week is protected against NDV. The highest antibody titter that is $9 \log 2$ to $10 \log 2$ was noted in both vaccinated and not vaccinated flock, may be suggestive of ND infection can be due to inappropriate management and not awareness of bio- security measures.

\section{Conclusion}

the level of protection of the vaccinated birds was found unsatisfactory which must be improved by hyper-immunizing the chickens before laying and by adopting good management conditions. The non-vaccinated birds have low antibody titter and this non-vaccinated broiler poultry in a future can be risk for the outbreak in broiler and other birds species like breeders.

Therefore, to prevent the outbreak of NDV infection strict policy must be adopted, such as limitation of movements in the farms. Biosecurity measures and continual boosting of bird's immunity with NDV vaccine can also be included in order to decrease economic losses usually caused by Newcastle disease outbreak. In poultry farms, the movement of crows must be control because crows eat bird's dead bodies and they spread the infection from one farm to another. The dead material of poultry birds should be burn and properly dumped. The properly managed farm prevents the transmission of aerosol and properly educate the farmers about biosecurity measures.

\section{References}

1. Sadiq M (2004) Pakistan poultry sector still on an upward swing. World Poultry 20: 10-11.

2. Alexander DJ (2000) The history of avian influenza in poultry. World Poultry, Elsevier special, pp: 7-8.

3. Nguyen TD (1992) Poultry production and Newcastle disease in Vietnam. In P. B. Spradbrow (Ed.): Newcastle disease in village chickens, control with thermostable oral vaccines. Proceeding No. 39 Aust. Center Intern. Agric. Res., Canberra, Australia, pp: 169-170.

4. Pearson GL, McCann MMK (1975) The role of indigenous wild, semidomestic and exotic birds in the epizootology of velogenic viscerotropic Newcastle disease in Southern California. J Amer Vet Med Assoc 167(7): 610-614.

5. Arshad M, Ajmal M, Rauf A, Rizvi AR, Naeem M (1988) Isolation of Newcastle disease virus from pigeons, starlings and sparrows from Faisalabad and Lahore districts, Pakistan. Pakistan J Zool 20 (4): 367371.

6. Wernery U, Remple JD, Neumann U, Alexander DJ, Manvel RJ, Kaaden OR (1992) Avian Paramyxovirus serotype 1 (Newcastle disease virus) infections in falcons. J Vet Med Series B 39(3): 153-158.

7. Tu TD, Phuc KV, Dinh NTK, Quoc DN, Spradbrow PB (1998) Vietnam trials with a thermostable vaccine (strain I2) in experimental and village chickens. Prev Vet Med 34(2-3): 205-214.

8. Allan WH, Gough RE (1974) A standard Haemagglutination Inhibition test for Newcastle disease. A comparison of macro and micro methods. Vet Rec 95(6): 120-123.

9. Siddique M, Sabri MA, Khan MZ (1986) Outbreak of Newcastle disease in vaccinated chicken flocks in and around Faisalabad [Pakistan]. Pakistan Veterinary Journal.

10. Dortmans JC, Peeters BP, Koch G (2012) Newcastle disease virus outbreaks: vaccine mismatch or inadequate application. Veterinary microbiology 160(1-2): 17-22.

11. Rezaeianzadeh G, Dadras H, Ali ASM, Nazemshirazi MH (2011) Serological and molecular study of Newcastle disease virus circulating in village chickens of Fars province, Iran. Journal of Veterinary Medicine and Animal Health 3(8): 105-111.

12. Hadipour MM (2009) A serological survey for Newcastle disease virus antibodies in backyard chickens around Maharlou Lake in Iran. Journal of Animal and Veterinary Advances 8(1): 59-61.

13. Aziz AGT, Ahmed TA (2010) Serological survey of Newcastle disease in domestic chickens in Sulaimani province. Journal of ZankoySulaimani 13(1): 41-45.

Your next submission with Juniper Publishers will reach you the below assets

- Quality Editorial service

- Swift Peer Review

- Reprints availability

- E-prints Service

- Manuscript Podcast for convenient understanding

- Global attainment for your research

- Manuscript accessibility in different formats

( Pdf, E-pub, Full Text, Audio)

- Unceasing customer service

Track the below URL for one-step submission https://juniperpublishers.com/online-submission.php 